\title{
Special Issue "Levering Sustainable Food Systems to Address Climate Change (Pandemics and Other Shocks and Hazards): Possible Transformations"
}

\author{
Andrew Spring ${ }^{1}\left(\right.$, Erin Nelson ${ }^{2}$, Irena Knezevic ${ }^{3}{ }^{\circledR}$, Patricia Ballamingie ${ }^{4}$ and Alison Blay-Palmer ${ }^{5, *}$ \\ 1 Laurier Centre for Sustainable Food Systems, Wilfrid Laurier University, Waterloo, ON N2L 6C2, Canada; \\ aspring@wlu.ca \\ 2 Department of Sociology and Anthropology, University of Guelph, Guelph, ON N1G 2W1, Canada; \\ enelson@uoguelph.ca \\ 3 School of Journalism and Communication, Carleton University, Ottawa, ON K1S 5B6, Canada; \\ Irena.Knezevic@carleton.ca \\ 4 Department of Geography and Environmental Studies, Carleton University, Ottawa, ON K1S 5B6, Canada; \\ patricia.ballamingie@carleton.ca \\ 5 Department of Geography and Environmental Studies, Wilfrid Laurier University, \\ Waterloo, ON N2L 6C2, Canada \\ * Correspondence: ablaypalmer@wlu.ca
}

Citation: Spring, A.; Nelson, E.;

Knezevic, I.; Ballamingie, P.;

Blay-Palmer, A. Special Issue

“Levering Sustainable Food Systems

to Address Climate Change

(Pandemics and Other Shocks and

Hazards): Possible Transformations".

Sustainability 2021, 13, 8206. https://

doi.org/10.3390/su13158206

Received: 14 July 2021

Accepted: 19 July 2021

Published: 22 July 2021

Publisher's Note: MDPI stays neutral with regard to jurisdictional claims in published maps and institutional affiliations.

Copyright: (C) 2021 by the authors. Licensee MDPI, Basel, Switzerland. This article is an open access article distributed under the terms and conditions of the Creative Commons Attribution (CC BY) license (https:// creativecommons.org/licenses/by/ $4.0 /)$.
Since we first conceived of this Special Issue, "Levering Sustainable Food Systems to Address Climate Change-Possible Transformations", COVID-19 has turned the world upside down. That said, while the pandemic has shifted our collective focus away from climate change and biodiversity loss (among other ecological challenges), it has also made people working in the realm of sustainability realize more acutely the urgency of addressing these issues. Building a more sustainable world-in which we all have access to healthy food; use renewable resources for power; regenerate our ecosystems; halt biodiversity loss; and enjoy dignified fair work - can help remedy many crises. It is even more relevant as we emerge from pandemic times that we double our efforts to advance towards a more just and sustainable future.

The bad news about climate change is well-known. According to the Intergovernmental Panel on Climate Change (IPCC) [1], we have until 2030 to enact unprecedented changes to avoid the catastrophic impacts of climate change, and to adapt to unavoidable climate disruption already underway. To achieve this, global carbon emissions must reach net zero by $2050[1,2]$. Researchers have demonstrated that sustainable food systems offer many solutions to confront this climate crisis [3,4]. This is a daunting task, requiring an overhaul of the existing industrially focused global food system, which currently contributes up to $37 \%$ of GHG emissions (IPCC 2018). As the world moves towards the Food System Summit convened by the UN General Assembly, the completion of the Global Framework on Biodiversity and the next Global Climate Change Conference in the fall of 2021, there is both hope for change and fear we will go even further down the profit-driven path that has precipitated the dire circumstances we now face.

However, it is clear we have the tools to make positive change happen. Evidence from multi-disciplinary, community-engaged research points to the key role played by regionally focused food systems that are circular, diverse, equitable and deliberative to serve as levers for change [3-7]. These systems offer transformative pathways for networks of people around the world to work together to build more biodiverse, culturally and economically diverse, adaptable and inclusive food communities [8].

\section{Multi-Shock Reality Check-What We Are Facing}

While it is impossible to see into the future, we will inevitably face pandemics again, and we are already experiencing dire consequences from climate change. The UNFCC [9] highlights the urgency of our time: "For many people across the world, climate change is 
already a matter of life and death. Yet we are still not doing enough to protect them. Nor are we doing enough to capitalize on the social, economic and environmental opportunities of climate action, which can enable economies and societies to thrive sustainably for decades to come" (p. 2). Further, we concur with their conclusion: "Our goal must be to keep global warming below 1.5 degrees Celsius, in line with the Intergovernmental Panel on Climate Change Special Report, which recommends greenhouse gas reductions of 45 per cent below 2010 levels by 2030, and net zero emissions by 2050" [9] (p. 2).

Coupled with the climate crisis, we face a crisis of food insecurity. While we produce more than enough calories for everyone on the planet, as of 2019, 690 million people were suffering food insecurity while more than 3 billion people could not afford a healthy diet [10]. The COVID-19 pandemic has drastically amplified these numbers, with estimates of acute hunger doubling from 149 million to 270 million [11]. Additionally, the FAO identifies poor diets as the number one cause of premature death globally $[10,12]$. While food insecurity may sometimes be thought of as primarily an issue in urban centres, high rates of rural poverty around the world mean that rural communities face this challenge as well. Ironically, the food insecurity rate is higher among farmers who, in some cases, cannot afford to feed themselves and their families year-round, even as they grow food to feed others [13].

Our options to adapt to the twin crises of climate change and food insecurity are further foreclosed as the diversity of crops and livestock declines. In recent decades, we have concentrated our diets on fewer and fewer crops, and farmed in ways that adversely impact surrounding species [14]. Up to $\$ 577$ billion US in crops is at risk annually due to pollinator loss, while $23 \%$ of land area has seen decreased food productivity [15]. Encroachment into the wild has been linked to transmission of zoonotic diseases, including COVID-19, SARS and Ebola [16]. The COVID-19 crisis demonstrates the fragility of current global supply chains [17]. This broken food system demands we foster more just and sustainable communities and share knowledge about how to produce, distribute and consume food differently.

In the face of the many threats posed by climate change, food insecurity and biodiversity loss, some experts promote one-track solutions that aim to grow more food through industrial intensification (e.g., Climate Smart Agriculture or Sustainable Intensification). A genuinely resilient food future, however, requires a shift from relying on high-emission petro-industrial farm inputs toward utilizing ecological cycles, solar and wind power, and the wisdom and knowledge of smallholders, ecological producers, and traditional and Indigenous communities practicing regenerative growing and harvesting [6,18].

Change is essential and non-negotiable. We need to seriously ask: how can this change happen? The sooner we act, the less disruptive it will be and the more options we will have. It requires shifts from linear to circular systems facilitated by bio/economic/socio-cultural diversity and engaged democratic participation $[4,19,20]$. Food is a big part of the solution.

\section{Why Food?}

Current food systems contribute 37\% of total GHG emissions [1] and thus offer a significant lever for change. Transportation, food waste, chemical applications and fossil fuels are some of the culprits. While the industrial food system is very productive, it represents a linear input-output approach that relies heavily on chemical and other industrial inputs to create a disproportionate amount of ultra-processed shelf-stable foods conducive to long-distance shipping. This model externalizes costs such as the destruction of ecosystems and farmer livelihoods, as well as the global health crisis associated with an industrial food diet [21-23]. By contrast, transforming this food system model creates opportunities to help tackle climate change, improve human health, mitigate biodiversity losses (including species extinctions), renew soil health and foster more inclusive societies. Food systems lie at the nexus of water, energy and waste and so consider the flows and circular synergies that can be leveraged for transformation. This paper lays out the evidence and the pathways to this change. 


\subsection{The Food System: Opportunities and Challenges for Sustainable Transformation}

Food systems-from seed to waste-provide a significant opportunity for tackling climate change and associated crises. However, while in many cases systems approaches are invoked, there is more often an over-simplification that does not capture the multiple benefits that can be achieved through sustainable food systems [24]. While we have begun to recognize the complexity of the food system, recent links between human and planetary health [25] over-simplify the problem and so do not offer viable solutions. For example, Sustainable Intensification (SI) as a production strategy ignores key issues regarding biodiversity, ecosystem health, community well-being, and food and nutrition security. Similarly, there is a tendency to focus on techno-fixes such as green roofs or storm water management, which precludes the opportunity for landscape-scale benefits. The current literature, with notable exceptions [26,27], focuses on one, or occasionally two, points in the food system (e.g., food security [28] and food production [29]).

Community-based research demonstrates that complex diverse food systems can reduce GHG emissions and climate pollution, while also improving community health and wellbeing, through diversity, circularity, and community participation and engagement. There are various entry points that can be integrated across social, ecological and economic considerations-keeping in mind that moving towards sustainability is as much a process as an end goal. Agroecology is a holistic approach to community food systems that includes a focus on biological, cultural and community diversity [30,31]:

"[...] based on bottom-up and territorial processes, helping to deliver contextualised solutions to local problems. Agroecological innovations are based on the co-creation of knowledge, combining science with the traditional, practical and local knowledge of producers. By enhancing their autonomy and adaptive capacity, agroecology empowers producers and communities as key agents of change. Rather than tweaking the practices of unsustainable agricultural systems, agroecology seeks to transform food and agricultural systems, addressing the root causes of problems in an integrated way and providing holistic and long-term solutions. This includes an explicit focus on social and economic dimensions of food systems. Agroecology places a strong focus on the rights of women, youth and indigenous peoples." [32] (p. 2)

There are now hundreds of case studies about the benefits of agroecology around the world. Examples include erva mate production using traditional methods in Brazil [33,34] and Paraguay [31], and the PIAL programme in Cuba, which started as a participatory plant-breeding project but now supports broader community development with an emphasis on social equity, including women's empowerment [35]. Biocultural diversity is particularly relevant in this context-encompassing interconnected biological, cultural and linguistic diversity - as well as the local knowledge, institutions and practices that collectively enable the adaptive management of farming systems, natural resources, landscapes and social lives [5]. Agroecological food systems work in closed-loop economic and ecological flows, so there is a circularity that reduces the distance between where things are made/grown and where they are disposed of [6]. The goal is to emulate nature where "everything moves in a circle" [6] (p. 922) so we have proportional composition and decomposition. Caution is needed when considering alternatives.

Territorial food systems are emerging to capture the multiple benefits of more coherent governance, with implications for social justice including food and nutrition security, fair livelihoods and ecological integrity. They also at times challenge the very premise of the market economy that underpins the neoliberal food system, by emphasizing social economy approaches and even non-monetary economies. Putting people before profits, paying living wages, promoting cooperative models, and developing community investment funds are just some of the ways social economy features in territorial food systems, while bartering, wildcrafting (foraging) and food sharing facilitate food distribution with no monetary exchange whatsoever [36]. Each of these activities chips away at the dominance of the neoliberal market economy. 


\subsection{Participation and Engagement}

Scholte's $[37,38]$ work on global democracy is interesting and instructive to consider in the context of sustainable food systems. Two threads are particularly relevant. The proposal of trans-scalarity, whereby scales are non-hierarchical and equally relevant, provides an opportunity to iterate between scales and demands a better articulation of governance so that members of civil society are empowered and enabled to bring about change both hierarchically and transversally. We see this as creating spatial kaleidoscopes that shift, inform and are informed by plural solidarities that build people power through interconnected diversity/inclusion, praxis and reflexivity $[38,39]$. Global governance needs to change so that it enables more "coherent and realistic solutions to global public policy challenges" [40] (p. 109) such as climate change, inequality, and food and nutrition insecurity.

Indigenous and traditional food systems, most of which have been co-evolving between people and landscapes for millennia [41], provide improved food access and biodiversity when Indigenous communities are most fully involved [42]. These food systems often use traditional harvesting and/or agroecological approaches that foster ecological and human health and support agricultural biodiversity and biocultural diversity [6] While these community-focused food systems bolster natural, social, financial, physical and cultural capital, they are often challenged due to constrained resources and capabilities through a lack of political capital [43]. As a result, they are overlooked as a source of much-needed innovation as we face climate change and other shocks.

The papers in this Special Issue bring to light important dimensions that need to be considered for sustainable food system success and transformation. All the papers describe local community initiatives as they work towards enhanced food sovereignty and food system resilience. They also clarify how sustainable food systems make communities more robust in the face of shocks and hazards and contribute to the health of people and our planet.

Blay-Palmer et al. (this Issue) delineate how City Region Food Systems (CRFS) represent one entry point into a territorial approach that can help to: enable multi-stakeholder engagement; foster linkages between rural, peri-urban and rural communities including bioregional food systems; support small-scale farmers and food processing and distribution businesses; and improve access to healthy food for all. Using examples from the COVID-19 pandemic, this paper reviews the contribution a CRFS approach makes to regional sustainability and resilience for existing and future shocks, including climate change. It includes both explicit interventions under United Nations Food and Agriculture Organization CRFS (FAO-RUAF)-led initiatives, as well as ad hoc efforts that engage with elements of the CRFS approach. The paper describes four key entry points for the CRFS approach-multistakeholder engagement; infrastructure; system-centred planning; and the role of policy in food system sustainability. The pandemic not only provides insights into how to enable more resilient food systems, but also offers lessons for future CRFS endeavours to address shocks including climate change (Blay-Palmer et al., this Issue).

Johnson and Spring take us to the Northwest Territories in Canada where communities are experiencing some of the most serious impacts of the global climate emergency. Despite the challenges, communities are finding ways to preserve livelihoods and foster adaptation. The paper also explores how relevant global governance helps NWT communities meet their needs, with a focus on a small community in the NWT. Successes in global partnership building and the lack of formal land tenure represent a significant barrier, and opportunities for global governance instruments and networks as pathways for dealing with climate change adaptation and food sovereignty are specifically addressed.

Using research in Italy and more specifically Rome during COVID-19, Zollet et al. document the resilience of small-scale, sustainable family farming and of spatially and socially embedded food systems as a counternarrative to the global supply chain. Surveys demonstrate how local community-defined action played a significant role in ensuring food access, provisioning and distribution, often in the face of delayed or insufficient action of mainstream food system actors and institutions. These responses elaborate opportunities 
and barriers for agri-food system transformation away from neoliberal, market-based interventions and towards policies that support food sovereignty and democracy in the context of localized, agroecology-based and more resilient agri-food systems.

\section{Conclusions}

The uneven evolution of power has resulted in powerful actors (e.g., corporations) that learn from and react to engagement with less powerful actors (e.g., CSOs) to enclose and capture increasing decision-making spaces at various levels of governance (Duncan 2015) [44]. The process leading to the upcoming World Food System Summit is an example of this in action. As Canfield et al. (2021) explain [11]:

"... it has become clear that the Summit is instead an effort by a powerful alliance of multinational corporations, philanthropies, and export-oriented countries to subvert the growing power of the Committee on World Food Security —an arena that since the 2007-08 global food crisis has emerged as the primary institution of public global food governance - as well as to capture the narrative of "food systems transformation"" (Canfield et al., 2021: 2) [11]

The clock is ticking. Sustainable food systems offer us a viable, fair, inclusive, rightsbased, diverse way forward towards transformation. Can we choose this path? Will we?

Author Contributions: Conceptualizing, writing, reviewing and editing: A.S., E.N., I.K., P.B., A.B.-P. All authors have read and agreed to the published version of the manuscript.

Funding: This research received no external funding.

Institutional Review Board Statement: Not applicable.

Informed Consent Statement: Not applicable.

Data Availability Statement: Not applicable.

Conflicts of Interest: The authors declare no conflict of interest.

\section{References}

1. IPCC. Global warming of $1.5^{\circ} \mathrm{C}$. In An IPCC Special Report on the Impacts of Global Warming of $1.5^{\circ} \mathrm{C}$ above Pre-Industrial Levels and Related Global Greenhouse Gas Emission Pathways, in the Context of Strengthening the Global Response to the Threat of Climate Change, Sustainable Development, and Efforts to Eradicate Poverty; Masson-Delmotte, V., Zhai, P., Pörtner, H.O., Roberts, D., Skea, J., Shukla, P.R., Pirani, A., Moufouma-Okia, W., Péan, C., Eds.; IPCC: Geneva, Switzerland, 2018.

2. Lewis, S.L.; Maslin, M.A. Defining the anthropocene. Nature 2015, 519, 171-180. [CrossRef]

3. Blay-Palmer, A.; Santini, G.; Dubbeling, M.; Renting, H.; Taguchi, M.; Giordano, T. Validating the city region food system approach: Enacting inclusive, transformational city region food systems. Sustainability 2018, 10, 1680. [CrossRef]

4. Knezevic, I.; Blay-Palmer, A.; Levkoe, C.Z.; Mount, P.; Nelson, E. (Eds.) Nourishing Communities: From Fractured Food Systems to Transformative Pathways; Springer: Cham, Switzerland, 2017.

5. Pimbert, M.P. (Ed.) Food Sovereignty, Agroecology and Biocultural Diversity: Constructing and Contesting Knowledge; Routledge: London, UK, 2017.

6. Qualman, D. Civilization Critical: Food, Energy, Nature and the Future; Fernwood Publishing: Halifax, Scotland, 2019.

7. Jurgilevich, A.; Birge, T.; Kentala-Lehtonen, J.; Korhonen-Kurki, K.; Pietikäinen, J.; Saikku, L.; Schösler, H. Transition towards circular economy in the food system. Sustainability 2016, 8, 69. [CrossRef]

8. Gibson-Graham, J.K.; Cameron, J.; Healy, S. Take Back the Economy: An Ethical Guide for Transforming Our Communities; U of Minnesota Press: Minneapolis, MN, USA, 2013.

9. UNFCCC. United Nations Annual Climate Change Annual Report. 2020. Available online: https://unfccc.int/sites/default/ files/resource/unfccc_annual_report_2019.pdf (accessed on 2 July 2021).

10. FAO; IFAD; UNICEF; WFP; WHO. The State of Food Security and Nutrition in the World 2020. Transforming Food Systems for Affordable Healthy Diets; FAO: Rome, Italy, 2020. [CrossRef]

11. WFP. New Report Shows Hunger Is Due to Soar as Coronavirus Obliterates Lives and Livelihoods. 2020. Available online: https:/ / www.wfp.org/news/new-report-shows-hunger-due-soar-coronavirus-obliterates-lives-and-livelihoods (accessed on 3 July 2021).

12. Canfield, M.; Anderson, M.D.; McMichael, P. UN Food Systems Summit 2021: Dismantling democracy and resetting corporate control of food systems. Front. Sustain. Food Syst. 2021, 5, 103. [CrossRef]

13. Joubert, L.S. The Hungry Season: Feeding Southern Africa's Cities; Picador Africa: Gordonsville, VA, USA, 2012. 
14. Biovision 2020. Annual Report. 2021. Available online: https://www.biovision.ch/fileadmin/pdf/Jahresberichte/Biovision-JB2 020_EN.pdf (accessed on 3 July 2021).

15. IPBES. Global Assessment Report on Biodiversity and Ecosystem Services of the Intergovernmental Science-Policy Platform on Biodiversity and Ecosystem Services; Brondizio, E.S., Settele, J., Díaz, S., Ngo, H.T., Eds.; IPBES Secretariat: Bonn, Germany, 2019; 1148p. [CrossRef]

16. Irving, A.T.; Ahn, M.; Goh, G.; Anderson, D.E.; Wang, L.F. Lessons from the host defences of bats, a unique viral reservoir. Nature 2021, 589, 363-370. [CrossRef] [PubMed]

17. Blay-Palmer, A.; Carey, R.; Valette, E.; Sanderson, M.R. Post COVID 19 and food pathways to sustainable transformation. Agric. Hum. Values 2020, 37, 517-519. [CrossRef]

18. Bayha, M.; Spring, A. Response to COVID in Délinę, NT: Reconnecting with our community, our culture and our past after the pandemic. Agric. Hum. Values 2020, 37, 597-598. [CrossRef]

19. Ballamingie, P.; Blay-Palmer, A.D.; Knezevic, I.; Lacerda, A.E.B.; Nimmo, E.R.; Stahlbrand, L.; Ayalon, R. Integrating a food systems lens into discussions of urban resilience: Analyzing the policy environment. J. Agric. Food Syst. Commun. Dev. 2020, 9 , 227-243.

20. Blay-Palmer, A.; Sonnino, R.; Custot, J. A food politics of the possible? Growing sustainable food systems through networks of knowledge. Agric. Hum. Values 2015, 33, 27-43. [CrossRef]

21. Mason, P.; Lang, T. Sustainable Diets: How Ecological Nutrition Can Transform Consumption and the Food System; Routledge: London, $\mathrm{UK}, 2017$.

22. Monteiro, C.A.; Levy, R.B.; Claro, R.M.; de Castro, I.R.R.; Cannon, G. Increasing consumption of ultra-processed foods and likely impact on human health: Evidence from Brazil. Public Health Nutr. 2010, 14, 5-13. [CrossRef]

23. Stuckler, D.; Nestle, M. Big food, food systems, and global health. PLoS Med. 2012, 9, e1001242. [CrossRef] [PubMed]

24. Knezevic, I.; Blay-Palmer, A. Multifunctionality in agriculture. In The SAGE Encyclopedia of Food Issues; Albala, K., Ed.; SAGE Publications: Thousand Oaks, CA, USA, 2015; pp. 996-1001.

25. Willett, W.; Rockström, J.; Loken, B.; Springmann, M.; Lang, T.; Vermeulen, S.; Garnett, T.; Tilman, D.; DeClerck, F.; Wood, A.; et al. Food in the anthropocene: The EAT-Lancet Commission on healthy diets from sustainable food systems. Lancet 2019, 393, 447-492. [CrossRef]

26. Bricas, N. Les enjeux de l'urbanisation pour la durabilité des systèmes alimentaires. In Construire des Politiques Alimentaires Urbaines. Concepts et Démarches; Editions Quae: Paris, France, 2017; pp. 19-38.

27. Vermeulen, S.J.; Campbell, B.M.; Ingram, J.S. Climate change and food systems. Annu. Rev. Environ. Resour. 2012, 37, 195-222. [CrossRef]

28. Wheeler, T.; Von Braun, J. Climate change impacts on global food security. Science 2013, 341, 508-513. [CrossRef] [PubMed]

29. Fischer, G.; Shah, M.M.; van Velthuizen, H.T. Climate Change and Agricultural Vulnerability; IIASA: Laxenburg, Austria, 2002.

30. Gliessman, S. Agroecology: The Ecology of Sustainable Food Systems; CRC Press: Boca Raton, FL, USA, 2015.

31. WWF. Farming with Biodiversity. Towards Nature-Positive Production at Scale; WWF International: Gland, Switzerland, 2021.

32. FAO. Ten Elements of Agroecology: Guiding the Transition to Sustainable Food and Agricultural Systems. 2018. Available online: http:/ / www.fao.org/3/I9037EN/i9037en.pdf (accessed on 2 July 2021).

33. Lacerda, A.E.B.; Hanisch, A.L.; Nimmo, E.R. Leveraging traditional agroforestry practices to support sustainable and agrobiodiverse landscapes in Southern Brazil. Land 2020, 9, 176. [CrossRef]

34. Nimmo, E.R.; de Carvalho, A.I.; Laverdi, R.; de Lacerda, A.E.B. Oral history and traditional ecological knowledge in social innovation and smallholder sovereignty: A case study of erva-mate in Southern Brazil. Embrapa Florestas-Artigo em periódico indexado (ALICE). Ecol. Soc. 2020, 25, 17. [CrossRef]

35. Benitez, B.; Nelson, E.; Romero Sarduy, M.I.; Ortíz Pérez, R.; Crespo Morales, A.; Casanova Rodríguez, C.; Campos Gómez, M.; Méndez Bordón, A.; Martínez Massip, A.; Hernández Beltrán, Y.; et al. Empowering women and building sustainable food systems: A case study of Cuba's local agricultural innovation project. Front. Sustain. Food Syst. 2020, 4, 219. [CrossRef]

36. Martin, M.A.; Knezevic, I.; Ballamingie, P. Social economy of food initiatives that are nourishing communities through power-with practices. Can. Food Stud. Rev. Can. Étud. Aliment. 2019, 6, 148-169. [CrossRef]

37. Scholte, J.A. Reinventing global democracy. Eur. J. Int. Relat. 2014, 20, 3-28. [CrossRef]

38. Scholte, J.A. After liberal global democracy: New methodology for new praxis. Fudan J. Hum. Soc. Sci. 2020, 13, 67-92. [CrossRef]

39. Wakefield, S.E. Reflective action in the academy: Exploring praxis in critical geography using a "food movement" case study. Antipode 2007, 39, 331-354. [CrossRef]

40. Coen, D.; Pegram, T. Towards a third generation of global governance scholarship. Glob. Policy 2018, 9, 107-113. [CrossRef]

41. Pascoe, B. Dark Emu: Aboriginal Australia and the Birth of Agriculture; Magabala Books: Broome, QC, Australia, 2018.

42. Schuster, R.; Germain, R.R.; Bennett, J.R.; Reo, N.J.; Arcese, P. Vertebrate biodiversity on indigenous-managed lands in Australia, Brazil, and Canada equals that in protected areas. Environ. Sci. Policy 2019, 101, 1-6. [CrossRef]

43. Spring, A. Capitals, Climate Change and Food Security: Building Sustainable Food Systems in Northern Canadian Indigenous Communities. Ph.D. Thesis, Wilfrid Laurier University, Waterloo, ON, Canada, 2018.

44. Duncan, J. Global Food Security Governance: Civil Society Engagement in the Reformed Committee on World Food Security; Routledge: London, UK, 2015. 